\title{
PARTISIPASI MASYARAKAT DESA BELANTING DALAM MELAKSANAKAN MUSYAWARAH PERENCANAAN PEMBANGUNAN DESA PADA PENYUSUNAN RENCANA KERJA PEMERINTAHAN DESA
}

\author{
I GUTI NGURAH ARYAWAN ASASANDI ${ }^{1)}$, MUHAMMAD AFZAL ${ }^{2)}$ \\ ${ }^{1)}$ Fak.Pertanian UNMAS Mataranm, 2) Fak.Hukum UNMAS Mataram \\ e-mail : ${ }^{1)}$ arya.sandi.as@gmail.com, ${ }^{2)}$ afzalalex369@gmil.com
}

ABSTRAK

Penelitian ini bertujuan untuk mengetahui tingkat partisipasi masyarakat desa dalam kegiatan musyawarah perencaaan pembangunan desa untuk menetapkan rencana kerja pemerintah desa (RKPDes). Desa Belanting dipilih menggunakan metode Perposive Sampling, dengan metode penelitian menggunakan Penelitian Deskriptif. Teknik Pengumpulan data penelitian menggunakan teknik observasi. Dari hasil disimpulkan : (1) Tingkat partisipasi kehadiran masyarakat tergolong tinggi, (2) Kendala yang dihadapi masyarakat ketika akan menghadapi kegiatan musyawarah perencaaan pembangunan adalah mepetnya surat undangan dalam kegiatan musrenbangdes.

Kata kunci : Partisipasi, Musyarawah

\section{ABSTRACT}

This study aims to determine the level of village community participation in village development planning meetings to establish village government work plans (RKPDes). Belanting village is chosen using the Perposive Sampling method, with the research method using Descriptive Research. The research data collection technique uses observation techniques. From the results concluded: (1) The level of participation of the community attendance is high, (2) The constraints faced by the community when facing the development planning meeting are the letter of invitation in the village planning meeting.

Keywords: Participation, Musyarawah

\section{PENDAHUUAN}

\section{Latar Belakang}

Sejak diberlakukannya Undang-undang tentang desa nomor 6 tahun 2014 maka kewenangan desa dalam mengatur segala sisi kehidupan masyarakat diberikan khusus oleh negara dalam hal ini pemerintah pusat termasuk dalam bidang pembangunan desa. Pada Pasal 79 ayat 1 Undang-undang Desa Nomor 6 Tahun 2014 berbunyi : "Pemerintah Desa menyusun perencanaan pembangunan desa sesuai dengan kewenangannya dan mengacu pada perencanaan pembangunan Kabupaten/Kota."

Perencanaan pembangunan merupakan suatu tahapan yang harus dilalui oleh desa dalam merubah kondisi masyarakat desa melalui suatu kegiatan pembangunan desa. Suatu perencanaan dikatakan baik apabila melibatkan masyarakat dari semua lapisan. Supriatna (1997) mengatakan bahwa pembangunan yang berorientasi pada pembangunan manusia mensyaratkan keterlibatan langsung masyarakat penerima program, agar hasil pembangunan sesuai dengan aspirasi dan kebutuhan masyarakat itu sendiri. Sedangkan menurut Todaro (2006), pembangunan harus mencerminkan perubahan total suatu masyarakat atau penyesuaian sistem sosial secara keseluruhan, tanpa mengabaikan keragaman kebutuhan dasar dan keinginan individu maupun kelompok-kelompok sosial yang ada didalamnya. Oleh karena itu pemerintah dalam menjalankan proses-proses pemerintahan dalam membangun masyarakat, khususnya masyarakat desa harus menekankan perlunya partisipasi masyarakat dengan beragam kepentingan ataupun latar belakang yang berbeda. Untuk mencapai keberhasilan pembangunan tersebut maka banyak aspek yang harus diperhatikan, diantaranya adalah keterlibatan masyarakat dalam perencanaan pembangunan. Dalam Peraturan Menteri dalam negeri nomor 114 tahun 2014 tentang pedoman pembangunan desa khususnya pasal 46 ayat 2 berbunyi : 
"Musyawarah Perencanaan Pembangunan Desa sebagaimana dimaksud ayat 1 diikuti oleh Pemerintah Desa, Badan Permusyawaratan Desa, dan Unsur Masyarakat."

Desa Belanting merupakan salah satu desa yang masuk dalam wilayah administratif Kecamatan Sambelia, Kabupaten Lombok Timur. Desa belanting memiliki 9 (Sembilan) dusun yang letaknya saling berjauhan. Dengan pola pembangunan yang partisipatif sesuai dengan amanah Permendagri nomor 114 tahun 2014 penelitian ini mencoba melihat bagaimana tingkat partisipasi masyarakat Desa Belanting dalam mengikuti kegiatan musyarah perencanaan pembangunan ini, atau yang disingkat menjadi Musrenbangdes.

\section{Tujuan Penelitian}

Tujuan Penelitian ini yaitu :

1. Untuk mengetahui seberapa jauh tingkat partisipasi masyarakat desa dalam kegiatan Musyawarah perencanaan Pembangunan (Musrenbangdes).

2. Untuk mengetahui tingkat partisipasi masyarakat dalam memberikan pendapat dalam kegiatan Musyawarah perencanaan Pembangunan (Musrenbangdes).

3. Untuk mengetahui apakah masyarakat mengikuti atau tidak alur yang ada pada kegiatan Musyawarah perencanaan Pembangunan (Musrenbangdes).

\section{METODE PENELITIAN}

Metode penelitian ini adalah penelitian deskriptif, karena dalam penelitian ini peneliti mencoba dalam mendeskripsikan sejauh mana tingkat partisipasi masyarakat desa ketika permerintah desa setempat menggelar acara Musrenbangdes. teknik pengumpulan data menggunakan teknik observasi dan wawancara langsung kepada peserta Musrenbangdes. Lokasi penelitian dipilih menggunkan metode Purposive Sampling yaitu Desa Belanting, Kecamatan Sambelia, Kabupaten Lombok Timur.

\section{HASIL DAN PEMBAHASAN}

\section{Karakteristik Responden}

\section{Usia Responden}

Faktor usia sangat menentukan seseorang untuk mengambil sebuah sikap dalam bertindak maupun berfikir. Apalagi dalam sebuah forum resmi seperti Musrenbangdes. Karakteristik responden dari segi usia berkisar pada rentang 20 tahun sampai 50 tahun (lebih jelas terdapat pada tabel 1).

Tabel 1. Kondisi Usia Responden

\begin{tabular}{|c|c|c|c|}
\hline No. & Rentang Usia (tahun) & Jumlah Responden (orang) & Persentase (\%) \\
\hline 1 & $20-30$ & 4 & 11,8 \\
\hline 2 & $31-40$ & 13 & 38,2 \\
\hline 3 & $41-50$ & 12 & 35,3 \\
\hline 4 & $51>$ & 5 & 14,7 \\
\hline \multicolumn{2}{|l|}{ Jumlah } & 34 & 100 \\
\hline
\end{tabular}

Sumber : Data Primer Diolah

Dari Tabel 1 tersebut dapat diketahui bahwa komposisi umur responden yang jumlahnya paling banyak adalah responden yang umurnya berkisar antara 31 sampai 40 tahun berjumlah 13 (tiga belas) orang atau 38,2 \%, responden yang berumur 20 sampai dengan 30 tahun berjumlah 4 (empat) orang atau 11,8 \%, responden yang berumur 41 sampai dengan 50 tahun berjumlah 12 (dua belas) orang atau 35,3\%, responden yang berumur diatas 50 tahun tahun berjumlah 5 (lima) orang atau 14,7\%.

\section{Tingkat Pendidikan Responden}

Latar belakang pendidikan seseorang akan mempengaruhi dalam kehidupannya di masyarakat. Di samping itu latar belakang pendidikan akan menjadi dasar berpikir dan mengungkapkan pendapat dalam mengambil keputusan termasuk di dalamnya dalam hal mengemukakan pendapat pada suatu forum musrenbangdes. Tabel 2 di bawah ini menyajikan data responden berdasarkan tingkat pendidikan. 
Tabel 2. Tingkat Pendidikan Responden

\begin{tabular}{|c|l|c|c|}
\hline No. & \multicolumn{1}{|c|}{ Tingkat Pendidikan } & Jumlah Responden (orang) & Persentase (\%) \\
\hline 1 & Sekolah Dasar & 5 & 14,7 \\
\hline 2 & Sekolah Menengah Pertama & 11 & 32,4 \\
\hline 3 & Sekolah Menengah Atas & 14 & 41,2 \\
\hline 4 & Perguruan Tinggi & 4 & 11,8 \\
\hline \multicolumn{2}{r}{ Jumlah } & 34 & 100 \\
\hline
\end{tabular}

Sumber : Data Primer Diolah

Dari Tabel 2 tersebut maka dapat diketahui yaitu tingkat pendidikan responden cukup beragam. Responden yang menyelesaikan tingkat pendidikan Sekolah Dasar adalah sebanyak 5 (lima) orang atau $14,7 \%$ dari jumlah populasi, responden yang memiliki tingkat pendidikan Sekolah Menengah Pertama sebanyak 11 (sebelas) orang atau 32,4\%, responden dengan tingkat penddidikan Sekolah Menengah Atas sebanyak 14 (empat belas) orang atau 41,2\%, dan yang terakhir responden yang memiliki tingkat pendidikan sarjana (S1) sebayak 4 (empat) orang atau 11,8\%. Dengan melihat tingkat pendidikan responden ini maka materi-materi yang disampaikan pada saat Musrenbangdes penetapan RKPDes di pastikan dapat diterima dengan baik.

\section{Mata Pencaharian Responden}

Faktor ini berkaitan dengan status ekonomi seseorang yang menjadi dasar keputusan dalam memberikan sebuah argumaen dan pendapat dalam ikut merencanakan sebuah pembangunan desa. berikut pada tabel 3 dipaparkan beberapa jenis mata pencaharian responden sebagai peserta musyawarah perencanaan pembangunan desa.

Tabel 3. Mata Pencaharian Responden

\begin{tabular}{|c|l|c|c|}
\hline No. & \multicolumn{1}{|c|}{ Tingkat Pendidikan } & Jumlah Responden (orang) & Persentase (\%) \\
\hline 1 & Wiraswasta & 4 & 11,8 \\
\hline 2 & Petani & 14 & 41,2 \\
\hline 3 & Nelayan & 2 & 5,9 \\
\hline 4 & Buruh tani & 11 & 32,4 \\
\hline 5 & ASN & 1 & 2,9 \\
\hline 6 & Ibu Rumah Tangga & 2 & 5,9 \\
\hline \multicolumn{2}{|r|}{ Jumlah } & 34 & 100 \\
\hline
\end{tabular}

\section{Sumber : Data Primer Diolah}

Dari Tabel 3 di atas terlihat bahwa beberapa jenis mata pencaharian dari responden yang ikut dalam kegiatan Musrenbangdes, tentunya hal ini akan sangat berpengaruh terhadap tingkat partisipasi masyarakat dalam mengikuti kegiatan Musrenbangdes. Dalam Tabel 3 terlihat bahwa sebanyak 4 (empat) orang atau $11,8 \%$ berprofesi sebagai wiraswasta, sebanyak 14 (empat belas) orang atau 41, $2 \%$ berprofesi sebagai petani, sebanyak 2 (dua)orang atau 5,9\% berprofesi sebagai nelayan, sebanyak 11 (sebelas) orang peserta atau 32,4\% dari populasi berprofesi sebagai buruh tani, 1 (satu) orang atau 2,9\% sebagai Aparatur Sipil Negara (ASN), dan yang terakhir sebanyak 2 (dua) orang atau sebanyak 5,9\% berprofesi sebagai Ibu Rumah Tangga (IRT).

\section{Tingkat Partisipasi Kehadiran Masyarakat}

Seseorang dapat berpartisipasi aktif dalam sebuah musyawarah atau pertemuan disebabkan oleh 2 (dua) faktor, pertama faktor internal dan kedua adalah faktor eksternal. Menurut Gibson dalam Nasution (2009) adalah:

\section{Faktor Sosial Ekonomi}

Faktor sosial ekonomi seperti tingkat pendidikan, pekerjaan dan pengalaman berkelompok menjadi penentu aktif tidaknya seseorang untuk berpartisipasi dalam pembangunan di desanya, khususnya untuk musyawarah perencanaan pembangunan desa. Faktor internal meliputi tingkat pendidikan, pekerjaan dan pengalaman berkelompok.

\section{a. Tingkat Pendidikan}

Seseorang dapat berpartisipasi aktif dalam pembangunan jika memiliki pendidikan yang baik karena pengetahuan, sikap, dan keterampilan erat hubungannya dengan pendidikan. Berdasarkan dari teori yang 
disampaikan oleh Gibson dalam Nasution (2009), apabila dikaitkan dengan hasil yang diperoleh dari lapangan, bahwa dengan pendidikan masyarakat yang tinggi sangat menetukan bagaimana masyarakat menyampaikan argumen dalam Musrenbang desa, masyarakat selalu mempertahankan usulannya, misalnya untuk perbaikan sarana jalan dan irigasi yang masuk dalam skala prioritas pembangunan desa, usulan tersebut sangat penting sekali untuk dipertahankan dalam Musrenbang desa bahkan ketika menjadi delegasi dusun yang akan memaparkan persoalan dusun yang ada di desa, maka peserta tersebut akan bertahan pada usulannya pada forum Musrenbang desa. Tingkat pendidikan masyarakat menentukan karena yang berpendidikan tinggi mempunyai wawasan luas jadi ketika beradu argumen dengan peserta lain, masyarakat tersebut lebih percaya diri dalam menyampaikan gagasannya. Responden dalam penelitian ini memiliki pendidikan sebagian besar adalah SMA yang menyebabkan antusias masayakat besar, sehingga tingkat partisipasi dalam kegiatan musrenbangdesa Di Desa Belanting tinggi.

\section{b. Pekerjaan}

Pekerjaan dapat mempengaruhi tingkat partisipasi dalam pembangunan. Pola pikir pada masyarakat umum, semakin sibuk seseorang semakin tidak mempunyai waktu berpartisipasi dalam pembangunan (Nasution, 2009). Selain itu juga pekerjaan yang identik dengan lingkungan pedesaan juga dapat mempengaruhi dari tingkat kehadiran masyarakat pada suatu agenda musyawarah. Dalam penelitian ini terlihat bahwa sebagian besar atau sebanyak 14 (empat belas) orang atau 41, 2\% berprofesi sebagai petani, oleh karena itu tingkat partisipasi masyarakat tinggi karena hal-hal yang dibicarakan juga menyangkut pembangunan pertanian dan pedesaan secara umum.

\section{c. Pengalaman Berkelompok}

Dengan pengalaman berkelompok yang dimiliki, membuat seseorang cenderung lebih berani dalam menyampaikan ide atau gagasan dalam suatu forum karena pada saat berorganisasi mereka terlatih untuk berpikir kritis dan tanggap dalam memecahkan masalah, serta mempunyai inisiatif dalam menyikapi perubahan di lingkungannya. Menurut Gibson dalam Nasution (2009), apabila dikaitkan dengan hasil yang diperoleh dari lapangan, bahwa dengan banyaknya pengalaman berkelompok yang masyarakat miliki, tidak lantas membuat mereka berpartisipasi dalam musyawarah perencanaan pembangunan desa. Seperti salah satu responden yaitu Bapak Lalu Rusni yang merupakan Ketua TPK (Tim Pelaksana Kegiatan) di desa maka akan sangat terdorong niatnya untuk menghadiri kegiatan Musrenbangdes ini.

\section{Sedangkan untuk faktor eksternal faktor-faktor penentu tingkat partisipasi adalah : Faktor Kepemimpinan}

\section{a. Memberikan Motivasi kepada Masyarakat.}

Kepemimpinan merupakan salah satu faktor yang menentukan keberhasilan dan keberlangsungan rencana pembangunan suatu desa karena pemimpin berfungsi sebagai pengendali dan penentu arah yang hendak ditempuh oleh desa menuju tujuan pembangunan yang akan dicapai dan sebagai kemampuan menggerakkan atau memotivasi sejumlah orang agar secara serentak melakukan kegiatan yang sama dan terarah pada pencapaian tujuannya. Menurut Tjokroamidjojo (1996) tentang sebuah motivasi, apabila dikaitkan dengan hasil yang diperoleh dari lapangan, dalam hal pemberian motivasi kepada masyarakat, Kepala Desa memberikan motivasi kepada masyarakat melalui pamflet, dan sosialisasi per RT/RW dengan harapan agar masyarakat berfikir dan mempunyai kreatifitas bahwa desa bukan hanya milik kepala desa dan perangkatnya namun juga milik masyarakat semua sehingga masyarakat ikut tergugah untuk ikut berpartisipasi dalam pelaksanaan musyawarah perencanaan pembangunan desa. Peran pemerintah dalam musrenbang desa adalah fungsinya sebagai regulator dan sosialisasi serta pendampingan, namun sosialisasi yang dilaksanakan kurang berhasil. Hal tersebut diungkapkan oleh Ibu Risnawati selaku anggota PKK Desa Belanting yang menuturkan bahwa kepala desa kurang memberikan motivasi kepada masyarakat pada umunya, karena sosialisasinya juga kurang kepada masyarakat kalangan menengah bawah.

\section{b. Tanggung Jawab Sebagai Seorang Pemimpin terhadap Setiap Keputusan yang Diambil.}

Tanggung jawab pemerintah desa dalam setiap pengambilan keputusan sangat krusial dalam kemajuan pembangunan desa dan untuk mengetahui baik buruknya keputusan yang diambil tidak bisa dinilai hanya dari konsekuensi yang ditimbulkan, namun juga melalui berbagai pertimbangan dalam prosesnya. Berdasarkan dari teori yang dikemukakan Tjokroamidjojo (1996), apabila dikaitkan dengan hasil yang diperoleh dari lapangan. Bentuk tanggung jawab yang dilakukan oleh Kepala Desa Sentul dalam merencanakan pembangunan desa adalah dengan mengambil keputusan atas dasar musyawarah mufakat mulai dari tingkat RT/RW dan Dusun lalu diangkat dalam Musrenbang desa. Pada saat Musrenbang desa 
menentukan skala prioritas pembangunan dari rencana pembangunan jangka menengah desa bersama masyarakat, LPMD, dan BPD. Jadi pengambilan keputusan yang bersifat partisipatif adalah mutlak untuk kepala desa, dimana masyarakat dan lembaga desa juga turut serta didalamnya. Bentuk tanggung jawab lembaga pemberdayaan masyarakat Desa Belanting dalam Musrenbang adalah dengan menyampaikan kepada masyarakat bahwa semua usulan pembangunan melibatkan elemen masyarakat dari bawah yaitu dari RT/RW lalu dirangkum menjadi usulan di musyawarah dusun dan selanjutnya dibawa ke tingkat desa. Jadi memberikan motivasi kepada masyarakat bahwa perencanaan pembangunan desa dibuat atas dasar aspirasi dari masyarakat.

\section{d. Keaktifan Pemimpin dalam Mendorong Berpartisipasi dan Memberi Perhatian Timbal Balik dengan} Masyarakat.

Kepemimpinan adalah kemampuan untuk mempengaruhi pihak lain, melalui komunikasi baik langsung maupun tidak langsung dengan maksud untuk menggerakkan orang-orang agar dengan penuh pengertian, kesadaran dan senang hati bersedia mengikuti kehendak pimpinan itu. Berdasarkan dari teori yang dikemukakan Tjokroamidjojo (1996), apabila dikaitkan dengan hasil yang diperoleh dari lapangan, keaktifan pemimpin dalam mendorong berpartisipasi dalam arti Kepala Desa Belanting menyadarkan dan mempengaruhi masyarakat agar berpartisipasi dalam Musrenbang desa, jadi bukan semata-mata menyuruh atau bahkan memaksa namun lebih kepada menyentuh nurani. Kepala Desa Belanting menyadarkan masyarakat akan pentingnya pembangunan partisipatif mulai dibentuk dari lembaga BPD dan LKMD. Bukan hanya masyarakat yang potensi saja yang memberikan masukan mengenai pembangunan desa, masyarakat yang sedia kalanya pasifpun bisa memberikan usulannya sehingga nanti diangkat oleh BPD dan LKMDmenjadi usulan desa.

\section{Kendala-kendala yang dihadapi}

Kendala yang dihadapi oleh responden dalam mengikuti kegiatan Musyawarah Perencanaan Pembangunan Desa (Musrenbangdes), yaitu surat undangan yang diberikan oleh pemerintah desa selaku penyelenggara terkesan mepet dengan hari pelaksanaannya sehingga persiapan dari responden sebagai peserta untuk mempersiapkan pertanyaan maupun masukan yang bersifat mendalam kepada forum musrenbangdes.

\section{SIMPULAN}

Dari hasil penelitian dapat disimpulkan sebagai berikut :

1. Tingkat partisipasi kehadiran masyarakat tergolong tinggi.

2. Kendala yang dihadapi masyarakat adalah surat undangan untuk melaksankan kegiatan Musrenbangdes mepet dengan hari pelaksanaannya..

\section{DAFTAR PUSTAKA}

Supriatna, Tjahya. 1997. Birokrasi. Pemberdayaan dan Pengentasan Kemiskinan. Jumadits Tsani Bandung.

Todaro, Michael P. dan Stephen C. Smith. 2006. Pembangunan Ekonomi (edisi kesembilan, jilid I). Erlangga Jakarta.

Republik Indonesia. 2014. Peraturan Menteri Dalam Negeri Nomor 114 tahun 2014 tentang Pedoman Pembangunan Desa. Berita Negara Republik Indonesia Tahun 2014 nomor 2094.

Soemarto, H.S., 2009, Inovasi, Partisipasi, dan Good Governance: 20 Prakarsa Inovatif dan Partisipatif di Indonesia, Jakarta. Yayasan Obor Indonesia.

Mardikanto, T., 1993, Penyuluhan Pembangunan Pertanian, Sebelas Maret Universitas Press. Surakarta

Eko, Sutoro.2005. Prakarsa Desentralisasi dan Otonomi Desa, IRE Press. Yogyakarta

Nasution, Zulkarnain. 2009. Solidaritas Sosial dan Partisipasi Masyarakat Desa Transisi. UMM Press. Malang

Tjokroamidjojo, Bintoro. 1995. Manajemen Pembangunan. Gunung Agung Jakarta 